\title{
The role of CYP19A1 and ESR2 gene polymorphisms in female androgenetic alopecia in the Polish population
}

\author{
Adriana Łukasik ${ }^{1}$, Karolina Kozicka ${ }^{1}$, Aleksandra Pisarek², Anna Wojas-Pelc ${ }^{1}$ \\ ${ }^{1}$ Department of Dermatology, Jagiellonian University Medical College, Krakow, Poland \\ ${ }^{2}$ Malopolska Centre of Biotechnology, Jagiellonian University, Krakow, Poland
}

Adv Dermatol Allergol 2022; XXXIX (4): 708-713
DOI: https://doi.org/10.5114/ada.2021.108429

\begin{abstract}
Introduction: Androgenetic alopecia is the most common type of non-cicatricial alopecia both in male and female patients. The mechanism that leads to hair loss is similar in both sexes, but the underlying cause, and especially the role of genes and sex hormones in the pathogenesis of the disease in women has not fully been explained as of yet. So far, a few attempts have been made to assess selected SNPs for CYP19A1 and ESR2 genes, but their results are not unequivocal and fully reproducible.

Aim: To investigate the association of 13 CYP19A1 and 11 ESR2 gene SNPs with female androgenetic alopecia (FAGA) in a population of Polish patients, including some already genotyped SNPs of possible importance for FAGA pathophysiology in other populations.

Material and methods: Twenty-four genetic polymorphisms were analysed for the ESR2 and CYP19A1 genes in 117 patients with FAGA and 128 healthy subjects treated at the Department of Dermatology in Krakow.

Results: In the studied Polish population, none of the selected SNPs, frequently detected in the Caucasian population and linked with the transformation pathway of sex hormones, showed a significant association with FAGA.

Conclusions: Further studies into the genetic background of androgenetic alopecia are needed. Ethnic differences as well as the size of the studied population may be of great significance for the obtained results.
\end{abstract}

Key words: female pattern hair loss, CYP19A1 gene, ESR2 gene, single nucleotide polymorphisms.

\section{Introduction}

Androgenetic alopecia is the most common type of non-cicatricial alopecia both in female and male patients. In both cases, the mechanism that leads to hair miniaturization is similar and involves a shortened anagen phase, and prolonged telogen and kenogen phases [1, 2]. The disease is chronic and progressive, leading to a gradual and diffuse hair loss in the central, parietal, and frontal scalp regions.

Amongst the numerous variables, including hormonal factors, that may impact the hair growth cycle in female androgenetic alopecia (FAGA), the role of androgens and oestrogens in the development of the disease remains unclear, especially given the fact that hormone levels are usually within normal ranges in FAGA patients [3-5].

Apart from the synthesis in the gonads and other organs, androgens and oestrogens are independently pro- duced in hair follicles, where they undergo mutual interactions, impacting gene transcription and expression [6].

Presently, more and more studies focus on the role of oestrogens and oestrogen receptors located in the skin and its structures, and in particular on ER- $\beta$ that is prevalent in hair follicles [7].

Both the CYP19A1 and ESR2 genes are involved in the transformation of sex hormones.

CYP19A1 is a gene located on chromosome 151, responsible for the production of aromatase, which is involved in the conversion of androgens (testosterone and androstenedione) into oestrogens [8]. Aromatase, similarly to $17 \beta$-HSD and $5 \alpha$-reductase, is an enzyme that is also located in the pilosebaceous units [9]. The higher levels of aromatase in the occipital regions, described by Sawaya et al., may be indicative of the protective role of oestrogens [10]. The ESR2 gene, located on chromosome 14,

Address for correspondence: Adriana Łukasik, Department of Dermatology, Jagiellonian University Medical College, 50 Kopernika St, 31-501 Krakow, Poland, phone: +48 505156 827, e-mail: adrianaluk@interia.pl Received: 11.01.2021, accepted: 8.06.2021. 
encodes the $\beta$ subtype (ER $\beta$ ) of intracellular nuclear oestrogen receptors.

To date, only a few studies have been carried out on the Chinese, Australian and European (UK, Germany) populations looking into the possible links between SNPS in the CYP19A1 and ESR2 genes and FAGA in women [11-15]. Some of the studies indicated significant correlations only with respect to a few selected SNPs: rs4646, rs6493497 and rs7176005 for the CYP19A1 gene, and rs10137185, rs17101774 and rs2022748 for the ESR2 gene.

So far, no attempt has been made to carry out a similar study involving a population of Polish patients.

\section{Aim}

The aim of the study was to investigate single nucleotide polymorphisms (SNPS) in the oestrogen-related genes ESR2 and CYP19A1 in order to examine whether they might be susceptible genes for FAGA development. We tried to replicate some findings of other authors and search for new SNPS of possible importance.

\section{Material and methods}

\section{Subjects}

117 FAGA patients and 128 healthy subjects, treated at the Department of Dermatology in 2017-2019, were included in the study. The diagnosis of androgenetic alopecia was confirmed by 2 dermatology specialists based on the typical history of the disease, its clinical picture, trichoscopic and histological examination.

The trichoscopic criteria of FAGA in videodermoscopy were based on the presence of 2 major criteria or 1 major and 2 minor criteria. Major criteria included an increased number of yellow dots (more than 4 yellow dots in the frontal area in 4 fields of vision at 70-fold magnification) and thin hairs, decreased average hair thickness in the frontal area and more than $10 \%$ of thin hairs $(<0.03 \mathrm{~mm})$ in the frontal area. Minor criteria included an increased frontal area to occiput ratio of single-hair units (> $2: 1)$, vellus hairs $(>1.5: 1)$ and follicles with perifollicular discoloration (> $3: 1)$ [16].

Exclusion criteria included co-existing diseases and medicines that could influence the hair loss.

The assessment of alopecia intensity was based on the 5-stage Sinclair scale. Table 1 presents the number of patients with individual stages of disease progression.

The patients' average age was 49.2 in the FAGA group, and 47.8 in the control group. In the FAGA study arm, 35 patients started suffering from FAGA before the age of 40 .

Approval for the study was obtained from the Bioethics Committee of the Jagiellonian University (decision no. 1072.6120.203.2017). All patients gave written consent for genetic studies.

\section{SNP selection}

SNP database "dbSNP" of the National Centre for Biotechnology Information was used to select the SNPs for analysis in the study [17]. The available polymorphisms, most frequently detected in the Caucasian population, with the genotype prevalence of at least 0.15 , were eventually chosen for the study.

With respect to the CYP19A1 gene, 13 SNPS were selected, and with respect to the ESR2 gene, 11 SNPs were selected for analysis in the study (Table 2) [18-27]. The SNPS were selected based on literature data. 4 SNPS were chosen for analysis based on their significance demonstrated in other studies carried out to date (rs4646, rs6493497, rs7176005 and rs10137185).

Polymorphisms rs12148604 and rs2899470 in the CYP19A1 gene are linked with the levels of sex hormones. The remaining SNPS have not been examined or described in the literature yet.

\section{Extraction of DNA}

Peripheral blood for molecular tests was collected in EDTA anticoagulant tubes. A 6\% solution of high-molecular weight dextran (Dextran T500, Pharmacia) was added to the whole blood for erythrocyte sedimentation. Leukocyte-rich plasma was drawn off and centrifuged for $10 \mathrm{~min} / 20000 \times \mathrm{g}$. DNA was isolated from white blood cells with the Chomczynski and Sacchi method (DNAzol, Gibco). $0.4 \mathrm{ml}$ of the DNAzol reagent was added to the centrifuged sediment and shaken. Following the dissolution of leukocyte cellular membranes, DNA was precipitated with $0.2 \mathrm{ml}$ of $95 \%$ ethyl alcohol. Afterwards, the isolated DNA was washed in $70 \%$ ethanol, and dried in an incubator at the temperature of $37^{\circ} \mathrm{C}$. Later on, the DNA was solubilized in redistilled water, and in that form used for further studies.

\section{Real-time PCR}

The isolated DNA was amplified and genotyped with the use of the real-time polymerase chain reaction (realtime P(R) method.

The real-time PCR reaction was carried out on 96well plates in the 7900 HT Real-Time PCR System (Applied Biosystems). A standard reaction mix included poly-

Table 1. Number of patients with particular grades of hair loss according to the Sinclair scale

\begin{tabular}{lc}
\hline Sinclair scale & Number of FAGA patients $(n=117)$ \\
\hline 1 & 1 \\
\hline 2 & 38 \\
\hline 3 & 33 \\
\hline 4 & 30 \\
\hline 5 & 15 \\
\hline
\end{tabular}


Table 2. Data for the SNP positions under study

\begin{tabular}{|c|c|c|c|c|c|c|c|}
\hline SNP & Gene & GRCh38 & $\begin{array}{c}\text { Allele } \\
\text { variants }\end{array}$ & MAF & Role & $\begin{array}{c}\text { Gene } \\
\text { consequence }\end{array}$ & Assay ID \\
\hline rs1152578 & ESR2 & chr14:64230319 & $\mathrm{T} / \mathrm{C}$ & T 0.424 & Not reported & Intron variant & C__1436977_10 \\
\hline rs1256065 & ESR2 & chr14:64232214 & $\mathrm{G} / \mathrm{T}$ & G 0.431 & $\begin{array}{l}\text { Associated with bone } \\
\text { mineral density [18] }\end{array}$ & Intron variant & C__1436975_10 \\
\hline rs8006145 & ESR2 & chr14:64232732 & $\mathrm{C} / \mathrm{A}$ & A 0.245 & Prostate volume [19] & Intron variant & C_29383989_10 \\
\hline rs867443 & ESR2 & chr14:64234324 & $\mathrm{G} / \mathrm{A}$ & A 0.238 & Not reported & Intron variant & C__1436972_20 \\
\hline rs17766755 & ESR2 & chr14:64249055 & $\mathrm{G} / \mathrm{A}$ & A 0.327 & $\begin{array}{l}\text { Benign prostatic } \\
\text { hyperplasia [20] }\end{array}$ & Intron variant & C_34495232_10 \\
\hline rs4365213 & ESR2 & chr14:64253546 & $\mathrm{T} / \mathrm{C}$ & C 0.412 & $\begin{array}{l}\text { Alzheimer disease in } \\
\text { women with Down } \\
\text { syndrome [21] }\end{array}$ & Intron variant & C_32395442_20 \\
\hline rs6573549 & ESR2 & chr14:64254931 & $\mathrm{T} / \mathrm{C}$ & C 0.422 & Not reported & Intron variant & C_ 32091355_10 \\
\hline rs61984409 & ESR2 & chr14:64263303 & $\mathrm{A} / \mathrm{C}$ & C 0.333 & Not reported & Intron variant & C_90266873_10 \\
\hline rs7154455 & ESR2 & chr14:64269942 & $\mathrm{G} / \mathrm{C}$ & C 0.290 & Not reported & Intron variant & C_29383994_10 \\
\hline rs960069 & ESR2 & chr14:64278284 & $\mathrm{C} / \mathrm{T}$ & C 0.443 & Not reported & Intron variant & C__1436935_10 \\
\hline rs10137185 & ESR2 & chr14:64309058 & $\mathrm{C} / \mathrm{T}$ & Т 0.100 & $\begin{array}{l}\text { Associated with FPHL } \\
\text { [22] }\end{array}$ & Intron variant & C_29621308_10 \\
\hline rs934634 & CYP19A1 & chr15:51208341 & $\mathrm{C} / \mathrm{T}$ & Т 0.190 & Not reported & $\begin{array}{l}\text { Intron variant, } 3 \\
\text { prime UTR variant }\end{array}$ & C__8794656_10 \\
\hline rs2255192 & CYP19A1 & chr15:51208638 & $\mathrm{C} / \mathrm{T}$ & Т 0.189 & Not reported & $\begin{array}{l}\text { Intron variant, } 3 \\
\text { prime UTR variant }\end{array}$ & C_15798398_10 \\
\hline rs4275794 & CYP19A1 & chr15:51208920 & $\mathrm{T} / \mathrm{C}$ & C 0.190 & Not reported & $\begin{array}{l}\text { Intron variant, } 3 \\
\text { prime UTR Variant }\end{array}$ & C_32394041_10 \\
\hline rs12148604 & CYP19A1 & chr15:51209207 & $\mathrm{C} / \mathrm{T}$ & C 0.424 & $\begin{array}{c}\text { Associated with sex } \\
\text { hormone levels (estrone) } \\
{[23]}\end{array}$ & $\begin{array}{l}\text { Intron variant, } 3 \\
\text { prime UTR variant }\end{array}$ & C_32071398_10 \\
\hline rs4646 & CYP19A1 & chr15:51210647 & $A / C$ & A 0.230 & $\begin{array}{c}\text { Associated with } \mathrm{FPHL}, \\
\text { premature ovarian failure } \\
{[12,24]}\end{array}$ & $\begin{array}{l}\text { Intron variant, } 3 \\
\text { prime UTR variant }\end{array}$ & C__8234730_1_ \\
\hline rs10046 & CYP19A1 & chr15:51210789 & $\mathrm{G} / \mathrm{A}$ & G 0.422 & $\begin{array}{l}\text { Associated with } \\
\text { miscarriages [25] }\end{array}$ & $\begin{array}{l}\text { Intron variant, } 3 \\
\text { prime UTR variant }\end{array}$ & C__8234731_30 \\
\hline rs2899470 & CYP19A1 & chr15:51211480 & $T / G$ & Т 0.348 & $\begin{array}{c}\text { Serum oestrogen and } \\
\text { oestrogen/testosterone } \\
\text { ratio [26] }\end{array}$ & Intron variant & C__8234732_10 \\
\hline rs12591172 & CYP19A1 & chr15:51211530 & $\mathrm{G} / \mathrm{A}$ & G 0.420 & Not reported & Intron variant & C__8234742_10 \\
\hline rs8029120 & CYP19A1 & chr15:51212737 & $T / G$ & Т 0.410 & Not reported & Intron variant & C__8234756_10 \\
\hline rs749292 & CYP19A1 & chr15:51266534 & $\mathrm{G} / \mathrm{A}$ & A 0.500 & $\begin{array}{l}\text { Associated with ovarian } \\
\text { cancer [27] }\end{array}$ & Intron variant & C__8801261_20 \\
\hline rs6493497 & CYP19A1 & chr15:51338638 & $\mathrm{G} / \mathrm{A}$ & A 0.092 & Associated with FPHL [11] & Upstream variant & C__29374681_10 \\
\hline rs7176005 & CYP19A1 & chr15:51339082 & $\mathrm{C} / \mathrm{T}$ & T 0.092 & Associated with FPHL [11] & Upstream variant & C_189237142_10 \\
\hline rs752760 & CYP19A1 & chr15:51339282 & $\mathrm{C} / \mathrm{T}$ & Т 0.385 & Not reported & Upstream variant & C__798312_10 \\
\hline
\end{tabular}

MAF-minor allele frequency, SNP - single nucleotide polymorphism, FAGA - female androgenetic alopecia.

merase and substrate solutions; TaqMan Universal PCR Master Mix, starters, probes, water, and DNA based on the manufacturer's recommendations (TaqMan Universal PCR Master Mix Protocol - Applied Biosystems). The probes and starters were purchased from Applied Biosystems in the form of ready-to-use TaqMan Gene Assays.

\section{Statistical analysis}

The study analysed 24 single nucleotide polymorphisms (SNP) located in the ESR2 and CYP19A1 genes (Table 2). Each genotype for 24 studied polymorphisms was coded in an additive way as 0,1 , or 2 considering the number of minor alleles. Genotype-phenotype as- 
sociation analyses were conducted using univariate binary logistic regression for FAGA defined as 1 (case) vs. 0 (control). Allelic odds ratios (ORs) with respective $95 \%$ confidence intervals (Cls) and $p$-values for the minor alleles classified in an additive manner were calculated (Table 3). Recessive and dominant modes of inheritance were also assessed where genotypes were coded as 0 and 1 vs. 2, and 0 vs. 1 and 2, respectively (Tables 4 and 5). Associations were tested using PS IMAGO PRO 6.0 (IBM SPSS Statistics 26).

\section{Results}

Univariate association analyses did not show statistical significance for any of the DNA variants of the ESR2 and CYP19A1 genes in the studied sample population (Table 3). No significant effects were also noted for a recessive and dominant manner of minor allele classification (Tables 4 and 5).

Table 3. Results of association analysis between individual SNP positions and FAGA

\begin{tabular}{|c|c|c|c|}
\hline SNP & Gene & OR $(95 \% \mathrm{Cl})$ & $P$-value \\
\hline rs1152578 & ESR2 & $1.092(0.755-1.581)$ & 0.640 \\
\hline rs1256065 & ESR2 & $1.153(0.799-1.665)$ & 0.446 \\
\hline rs8006145 & ESR2 & $0.883(0.561-1.391)$ & 0.592 \\
\hline rs867443 & ESR2 & $0.941(0.597-1.483)$ & 0.793 \\
\hline rs17766755 & ESR2 & $1.070(0.713-1.607)$ & 0.743 \\
\hline rs4365213 & ESR2 & $0.992(0.685-1.436)$ & 0.967 \\
\hline rs6573549 & ESR2 & $1.007(0.699-1.452)$ & 0.969 \\
\hline rs61984409 & ESR2 & $0.966(0.648-1.441)$ & 0.865 \\
\hline rs7154455 & ESR2 & $0.870(0.563-1.346)$ & 0.533 \\
\hline rs960069 & ESR2 & $1.124(0.776-1.628)$ & 0.535 \\
\hline rs10137185 & ESR2 & $0.892(0.502-1.584)$ & 0.697 \\
\hline rs934634 & CYP19A1 & $1.151(0.728-1.820)$ & 0.547 \\
\hline rs2255192 & CYP19A1 & $1.073(0.678-1.698)$ & 0.763 \\
\hline rs4275794 & CYP19A1 & $1.032(0.653-1.630)$ & 0.894 \\
\hline rs12148604 & CYP19A1 & $0.917(0.636-1.323)$ & 0.645 \\
\hline rs4646 & CYP19A1 & $0.860(0.554-1.335)$ & 0.501 \\
\hline rs10046 & CYP19A1 & $0.970(0.671-1.401)$ & 0.870 \\
\hline rs2899470 & CYP19A1 & $0.980(0.660-1.455)$ & 0.919 \\
\hline rs12591172 & CYP19A1 & $0.947(0.654-1.371)$ & 0.771 \\
\hline rs8029120 & CYP19A1 & $0.893(0.607-1.314)$ & 0.566 \\
\hline rs749292 & CYP19A1 & $1.171(0.824-1.663)$ & 0.378 \\
\hline rs6493497 & CYP19A1 & $1.396(0.762-2.558)$ & 0.280 \\
\hline rs7176005 & CYP19A1 & $1.404(0.766-2.574)$ & 0.272 \\
\hline rs752760 & CYP19A1 & $0.987(0.678-1.438)$ & 0.947 \\
\hline
\end{tabular}

$\mathrm{Cl}$ - confidence interval, OR - odds ratio, SNP - single nucleotide polymorphism.

\section{Discussion}

Many hormones, including the thyroid, adrenal, pineal and pituitary gland hormones, impact the hair growth cycle [28]. Oestrogens are usually believed to have protective qualities [3, 29, 30], even though some studies indicate that hair growth is slowed under their influence due to the initiation of an earlier catagen phase, and prolongation of telogen phase [31].

With respect to the CYP19A1 gene, Yip et al. demonstrated a statistically significant incidence of the CC genotype for polymorphism rs4646 in their study carried out in Australia [12]. Johansson et al. described higher oestrogen levels in patients with that genotype, what could substantiate the hypothesis that the hair growth cycle is inhibited under the influence of oestrogens [32].

Redler et al. failed to confirm the findings of Yip et al. in a study involving the German and British populations

Table 4. Results of association analysis between individual SNP positions and FAGA for a recessive model of allele classification

\begin{tabular}{lccc}
\hline SNP & Gene & OR $(95 \% \mathrm{Cl})$ & $P$-value \\
\hline rs1152578 & ESR2 & $0.833(0.424-1.638)$ & 0.597 \\
\hline rs1256065 & ESR2 & $0.948(0.490-1.836)$ & 0.875 \\
\hline rs8006145 & ESR2 & $0.439(0.083-2.311)$ & 0.331 \\
\hline rs867443 & ESR2 & $0.444(0.084-2.340)$ & 0.338 \\
\hline rs17766755 & ESR2 & $1.013(0.395-2.600)$ & 0.978 \\
\hline rs4365213 & ESR2 & $1.090(0.544-2.184)$ & 0.808 \\
\hline rs6573549 & ESR2 & $1.048(0.535-2.053)$ & 0.890 \\
\hline rs61984409 & ESR2 & $0.826(0.334-2.047)$ & 0.680 \\
\hline rs7154455 & ESR2 & $0.411(0.105-1.605)$ & 0.201 \\
\hline rs960069 & ESR2 & $0.904(0.469-1.742)$ & 0.762 \\
\hline rs10137185 & ESR2 & $0.350(0.036-3.417)$ & 0.366 \\
\hline rs934634 & CYP19A1 & $1.844(0.430-7.909)$ & 0.410 \\
\hline rs2255192 & CYP19A1 & $1.860(0.434-7.981)$ & 0.404 \\
\hline rs4275794 & CYP19A1 & $1.844(0.430-7.909)$ & 0.410 \\
\hline rs12148604 & CYP19A1 & $0.797(0.408-1.560)$ & 0.509 \\
\hline rs4646 & CYP19A1 & $0.734(0.202-2.673)$ & 0.640 \\
\hline rs10046 & CYP19A1 & $0.939(0.479-1.840)$ & 0.854 \\
\hline rs2899470 & CYP19A1 & $0.960(0.410-2.248)$ & 0.924 \\
\hline rs12591172 & CYP19A1 & $0.887(0.449-1.754)$ & 0.730 \\
\hline rs8029120 & CYP19A1 & $0.648(0.308-1.366)$ & 0.254 \\
\hline rs749292 & CYP19A1 & $1.082(0.610-1.921)$ & 0.787 \\
\hline rs6493497 & CYP19A1 & $2.390(0.212-26.988)$ & 0.481 \\
\hline rs7176005 & CYP19A1 & $2.390(0.212-26.988)$ & 0.481 \\
\hline rs752760 & CYP19A1 & $1.621(0.771-3.410)$ & 0.203 \\
\hline C 2009
\end{tabular}

$\mathrm{Cl}$-confidence interval, OR - odds ratio, SNP - single nucleotide polymorphism. 
Table 5. Results of association analysis between individual SNP positions and FAGA for a dominant model of allele classification

\begin{tabular}{lccc}
\hline SNP & Gene & OR $(95 \% \mathrm{Cl})$ & $P$-value \\
\hline rs1152578 & ESR2 & $1.361(0.790-2.346)$ & 0.267 \\
\hline rs1256065 & ESR2 & $1.421(0.822-2.456)$ & 0.208 \\
\hline rs8006145 & ESR2 & $0.935(0.565-1.547)$ & 0.793 \\
\hline rs867443 & ESR2 & $1.010(0.609-1.674)$ & 0.971 \\
\hline rs17766755 & ESR2 & $1.108(0.666-1.843)$ & 0.692 \\
\hline rs4365213 & ESR2 & $0.935(0.549-1.594)$ & 0.806 \\
\hline rs6573549 & ESR2 & $0.985(0.576-1.685)$ & 0.957 \\
\hline rs61984409 & ESR2 & $1.005(0.604-1.671)$ & 0.986 \\
\hline rs7154455 & ESR2 & $0.954(0.576-1.579)$ & 0.855 \\
\hline rs960069 & ESR2 & $1.399(0.801-2.442)$ & 0.238 \\
\hline rs934634 & CYP19A1 & $1.109(0.654-1.878)$ & 0.702 \\
\hline rs2255192 & CYP19A1 & $1.008(0.594-1.712)$ & 0.975 \\
\hline rs4275794 & CYP19A1 & $0.958(0.566-1.624)$ & 0.874 \\
\hline rs12148604 & CYP19A1 & $0.961(0.561-1.646)$ & 0.885 \\
\hline rs4646 & CYP19A1 & $0.856(0.513-1.428)$ & 0.552 \\
\hline rs10046 & CYP19A1 & $0.975(0.570-1.668)$ & 0.926 \\
\hline rs2899470 & CYP19A1 & $0.980(0.587-1.639)$ & 0.940 \\
\hline rs12591172 & CYP19A1 & $0.960(0.561-1.644)$ & 0.881 \\
\hline rs8029120 & CYP19A1 & $1.012(0.590-1.735)$ & 0.965 \\
\hline rs749292 & CYP19A1 & $1.416(0.792-2.529)$ & 0.240 \\
\hline rs6493497 & CYP19A1 & $1.401(0.719-2.733)$ & 0.322 \\
\hline rs752760 & CYP19A1 & $0.765(0.454-1.292)$ & 0.317 \\
\hline CYP19A1 & $1.410(0.723-2.750)$ & 0.313 \\
\hline CS0nif & $0.957(0.500-1.831)$ & 0.894 \\
\hline
\end{tabular}

$\mathrm{Cl}$ - confidence interval, OR - odds ratio, SNP - single nucleotide polymorphism.

[13]. In a study of Rui et al. involving the Chinese population, a statistically significant difference was observed with respect to the distribution of alleles in polymorphisms rs6493497 and rs7176005, but no correlation was found for rs4646 either [11].

As regards the ESR2 gene, Yip et al. indicated the significance of rs10137185, rs17101774, and rs2022748 polymorphisms in the Australian population [14].

Even though initially Redler et al. did not observe any significant correlations in the German and British populations, they did confirm the significance of rs10137185 in a later study involving the German population only. The authors pointed to potentially important variables such as the number of patients included in the study and a later stage of alopecia progression [22].

That proposition is confirmed by the results obtained in a study conducted by Yip et al., which involved the largest group of subjects (484 FAGA patients and 471 control subjects) [12].
In our study, we searched for correlations that would be true for the entire group of patients, taking into account the severity grade of alopecia, however the small number of patients with advanced grade of hair loss might have impacted the final results, leading to a lack of agreement with Redler's study results.

The number of patients included in our study was sufficient to assess allele frequency in the Polish population, but it might be too small to reach the threshold of statistical significance.

\section{Conclusions}

Numerous studies carried out so far on FAGA etiopathogenesis have not been successful at explicating the role of genes or sex hormones in the development of the disease.

Our study showed no association of CYP19A1 and ESR2 genes with FAGA in the Polish population, although some of the SNPs included in our research showed a statistically significant incidence in Australian, Chinese and German populations.

As the small size of the studied group could be the reason for no findings regarding the selected SNPS, it prompts us to conclude that further research is needed that would include more patients.

It is also possible that another variant in the CYP19A1 and ESR2 gene is associated with FAGA in the Polish population.

Due to the suspected possibility of communication and co-dependence of receptor pathways for steroid hormones like oestrogens and androgens, it is also necessary to look into the functioning of hormones, and a potential impact of genes on hormonal activity [33, 34].

Undoubtedly, the high costs incurred in the course of studies remain one of the limitations involved.

\section{Conflict of interest}

The authors declare no conflict of interest.

\section{References}

1. Guarrera M, Rebora A. Kenogen in female androgenetic alopecia. A longitudinal study. Dermatology 2005; 210: 18-20.

2. Messenger AG, Sinclair R. Follicular miniaturization in female pattern hair loss: clinicopathological correlations. $\mathrm{Br} J$ Dermatol 2006; 155: 926-30.

3. Mesinkovska NA, Bergfeld WF. Hair: what is new in diagnosis and management? Female pattern hair loss update: diagnosis and treatment. Dermatol Clin 2013; 31: 119-27.

4. Schmidt TH, Shinkai K. Evidence-based approach to cutaneous hyperandrogenism in women. J Am Acad Dermatol 2015; 73: 672-90.

5. Yip L, Rufaut N, Sinclair R. Role of genetics and sex steroid hormones in male androgenetic alopecia and female pattern hair loss: an update of what we now know. Australas J Dermatol 2011; 52: 81-8. 
6. Ohnemus U, Uenalan M, Inzunza J, et al. The hair follicle as an estrogen target and source. Endocrine Rev 2006; 27: 677706.

7. Brandenberger AW, Tee MK. Lee JY, et al. Tissue distribution of estrogen receptors $\alpha(E R-\alpha)$ and $\beta$ (ER- $\beta)$ mRNA in the midgestational human fetus. J Clin Endocrinol Metab 1997; 82: 3509-12.

8. Czajka-Oraniec I, Simpson ER. Aromatase research and its clinical significance. Endokrynol Pol 2010; 61: 126-34.

9. Sperling L, Sinclair R, Shabrawi-Caelen L. Alopecias. In: Dermatology. $3^{\text {rd }}$ ed. Bolognia JL, Jorizzo JL, Schaffer JV (eds.). Elsevier, Amsterdam 2012; 547.

10. Sawaya ME, Price VH. Different levels of 5alpha-reductase type I and II, aromatase, and androgen receptor in hair follicles of women and men with androgenetic alopecia. J Invest Dermatol 1997; 109: 296-300.

11. Rui W, Sheng Y, Hu R, et al. Association of single nucleotide polymorphisms in the CYP19A1 gene with female pattern hair loss in a Chinese population. Dermatology 2015; 231: 239-44.

12. Yip L, Zaloumis S, Irwin D, et al. Gene-wide association study between the aromatase gene (CYP19A1) and female pattern hair loss. Br J Dermatol 2009; 161: 289-94.

13. Redler S, Birch MP, Drichel D, et al. Investigation of variants of the aromatase gene (CYP19A1) in female pattern hair loss. $\mathrm{Br}$ J Dermatol 2011; 165: 703-5.

14. Yip L, Zaloumis S, Irwin D, et al. Association analysis of oestrogen receptor beta gene (ESR2) polymorphisms with female pattern hair loss. Br J Dermatol 2012; 166: 1131-4.

15. Redler S, Tazi-Ahnini R, Drichel D, et al. Selected variants of the steroid-5-alpha-reductase isoforms SRD5A1 and SRD5A2 and the sex steroid hormone receptors ESR1, ESR2 and PGR: no association with female pattern hair loss identified. Exp Dermatol 2012; 21: 390-3.

16. Brzezińska-Wcisło L, Rakowska A, Rudnicka L, et al. Androgenetic alopecia. Diagnostic and therapeutic recommendations of the Polish Dermatological Society. Dermatol Rev 2018; 105: 1-18.

17. Sherry ST, Ward MH, Kholodov M, et al. dbSNP: the NCBI database of genetic variation. Nucleic Acids Res 2001; 29: 308-11.

18. Greendale GA, Chu J, Ferrell R, et al. The association of bone mineral density with estrogen receptor gene polymorphisms. Am J Med 2006; 119 (9 Suppl 1): 79-86.

19. Cornu JN, Audet-Walsh E, Drouin S, et al. Correlation between prostate volume and single nucleotide polymorphisms implicated in the steroid pathway. World J Urol 2017; 35: 293-8.

20. Kim SK, Chung JH, Park HC, et al. Association between polymorphisms of estrogen receptor 2 and benign prostatic hyperplasia. Exp Ther Med 2015; 10: 1990-4.

21. Zhao Q, Lee JH, Pang D, et al. Estrogen receptor-Beta variants are associated with increased risk of Alzheimer's disease in women with down syndrome. Dement Geriatr Cogn Disord 2011; 32: 241-9.

22. Redler S, Birch P, Drichel D, et al. The oestrogen receptor 2 (ESR2) gene in female-pattern hair loss: replication of association with rs10137185 in German patients. Br J Dermatol 2014; 170: 982-5.

23. Kidokoro K, Ino K, Hirose K, et al. Association between CYP19A1 polymorphisms and sex hormones in postmenopausal Japanese women. J Hum Genet 2009; 54: 78-85.
24. Kim S, Pyun JA, Cha DH, et al. Epistasis between FSHR and CYP19A1 polymorphisms is associated with premature ovarian failure. Fertil Steril 2011; 95: 2585-8.

25. Cupisti S, Fasching PA, Ekici AB, et al. Polymorphisms in estrogen metabolism and estrogen pathway genes and the risk of miscarriage. Arch Gynecol Obstet 2009; 280: 395-400.

26. Jiang J, Tang NLS, Ohlsson C, et al. Association of genetic variations in aromatase gene with serum estrogen and estrogen/testosterone ratio in Chinese elderly men. Clin Chim Acta 2010; 411: 53-8.

27. Goodman MT, Lurie G, Thompson PJ, et al. Association of two common single-nucleotide polymorphisms in the CYP19A1 locus and ovarian cancer risk. Endocr Relat Cancer 2008; 15: 1055-60.

28. Paus R, Foitzik K. In search of the "hair cycle clock": a guided tour. Differentiation 2004; 72: 489-511.

29. Park J, Kim JI, Yun SK, et al. Pattern alopecia during hormonal anticancer therapy in patients with breast cancer. Ann Dermatol 2014; 26: 743-6.

30. Levy LL, Emer JJ. Female pattern alopecia: current perspectives. Int J Womens Health 2013; 5: 541-56.

31. Hu HM, Zhang SB, Lei XH, et al. Estrogen leads to reversible hair cycle retardation through inducing premature catagen and maintaining telogen PLoS One 2012; 7: e40124.

32. Johansson H, Aristarco V, Gandini S, et al. Prognostic impact of genetic variants of CYP19A1 and UGT2B17 in a randomized trial for endocrine-responsive postmenopausal breast cancer. Pharmacogenomics J 2020; 20: 19-26.

33. Thornton MJ. The biological actions of estrogens on skin. Exp Dermatol 2002; 11: 487-502.

34. Stenn KS, Paus R. Controls of hair follicle cycling. Physiol Rev 2001; 81: 449-94. 